\title{
Museum Notes
}

\section{Bone May Give Earliest Evidence of Man in Iowa}

A prehistoric mammoth or mastodon bone was found in late August in a Des Moines gravel pit and donated to the Iowa State Museum in the Historical Building. The bone has unusual markings cut into its surface which may prove to be the earliest evidence yet found of man in Iowa.

Mastodon and mammoth bones are not particularly rare in Iowa, but the evidence of early man found in association with them is. It is believed that the ten or more grooves worn into the surface of this bone were made by early man. Most of the grooves are rounded at the bottom, but a particularly deep one shows flat, sloping sides and a nearly flat bottom. It seems quite probable that the markings and the man who made them must be about as old as the bone and the deposit of gravel in which it was found-about fifteen or twenty thousand years.

It is believed that whatever instrument was used to make the marks must have removed the bone rather slowly for it left a depression that has retained its polish through the years. The bone was found in glacial gravel which lies below twelve to fifteen feet of silt accumulated from numerous floodings of the Des Moines River.

In North America, the evidence of man found in association with these ancient mammals has occurred less than a dozen times. This is the first occurrence in Iowa.

The bone is on display at the Iowa State Museum, Historical Building, Des Moines. 
Copyright of Annals of Iowa is the property of State of Iowa, by \& through the State Historical Society of Iowa and its content may not be copied or emailed to multiple sites or posted to a listserv without the copyright holder's express written permission. However, users may print, download, or email articles for individual use. 